\title{
Evaluation of fitness for work in a Case with COPD
}

\section{КОАH Tanılı Bir Olguda İşe Uygunluk Değerlendirmesi}

Merve Demirci Atik, Ayse Coskun Beyan, Arif Hikmet Çımrın

\section{Abstract}

Today, approximately $25 \%$ of the working populations have at least one chronic disease, and so the delineation "fitness for work" is quite important. The process for the evaluation of fitness for work is evaluated in this paper, alongside a detailed work analysis and a further functional evaluation of an employee who presented to our work and occupational illnesses clinic with a diagnosis of chronic obstructive pulmonary disease (COPD). A 39-year-old male with the diagnosis of COPD, who was employed at a rim factory, was subjected to a cardiopulmonary exercise test, and a work analysis revealed that the energy requirement of the work was above the acceptable limits for the case. The smoke, dust and metal identified in the environment were thought to contribute to the exacerbation and progression of COPD. Modifications to the patients work to suit his cardiopulmonary capacity, and reducing the defined risks was suggested. Evaluating work compatibility is an important area of study requiring the collaboration of many disciplines, and occupational disease specialists in particular, with the am being to protect the health of the workforce and the continuity of works.

Key words: COPD, functional evaluation, fitness for work.

\section{Özet}

Günümüzde çalışan nüfusun, yaklaşık \%25'inde en az bir kronik hastalık vardır. Bu nedenle "işe uygunluk kavramı" oldukça önem taşımaktadır. Bu yazıda kronik obsrüktif akciğer hastalığı (KOAH) tanısı ile iş ve meslek hastalıkları kliniğimize başvuran bir çalışanın, işe uygunluk süreci; detaylı iş analizi ve ileri fonksiyonel inceleme ile birlikte değerlendirilmiştir. İki yıldır KOAH tanısı olan 39 yaşında erkek, jant fabrikasında çalışmaktaydı. Yapılan kardiyopulmoner egzersiz testi ve iş analizi sonucunda yaptığı işin enerji gereksiniminin, olgunun kabul edilebilir limit değerlerinin üzerinde olduğu belirlendi. Ortamdaki toz ve metal dumanının da KOAH alevlenmesine ve progresyonuna katkısı olabileceği düşünüldü. Tanımlanan risklerden uzak kalacak ve kardiopulmoner kapasitesine uygun şekilde iş modifikasyonu yapılması önerildi. İşe uygunluk değerlendirmesi, iş ve meslek hastalıkları uzmanları başta olmak üzere pek çok disiplinin bir arada çalışmasının gerektiği, çalışanın sağlığı ve işin devamını korumayı amaçlayan önemli bir alandır.

Anahtar Sözcükler: KOAH, isşe uygunluk, fonksiyonel değerlendirme.

Department of Occupational Medicine, Dokuz Eylul University, Izmir, Turkey Bilim Dalı, ̇̇zmir

Submitted (Başvuru tarihi): 03.06.2020 Accepted (Kabul tarihi): 12.08.2020

Correspondence (iletişim): Merve Demirci Atik, Department of Occupational Medicine, Dokuz Eylul University, lzmir, Turkey

e-mail: merve_ci@hotmail.com 
Factors such as the relative increase in the elderly population and the increase in retirement age have increased the incidence of chronic diseases in the working population (1). In addition, many people need to work after retirement due to financial concerns, or to continue to be a part of social life. It is important, therefore, to provide workers with working conditions that will not be detrimental to their health, and that will safeguard their productivity. Evaluations of work compatibility are the basic method used to ensure these conditions (2).

COPD is the third leading cause of death worldwide (3). Only half of all patients are thought to be diagnosed, although only one in five individuals over the age of 40 years is known to have COPD (4). The prevalence of COPD has been increasing in both developed and developing countries as a result of environmental and occupational exposure; including tobacco use, air pollution, and the increasing elderly population and biomass smoke (5). While the disease is generally associated with advanced age, according to estimations, 50\% of patients with COPD are under the age of 65 , and most are in paid employment (6). Quality of life is impaired secondary to decreased effort capacity in the advanced stages of the disease, leading to a decreased participation in daily activities. This in turn can limit substantially the participation of individuals in occupational life. It is a known fact that approximately $20 \%$ of patients with COPD leave their working life early due to the effects of their disease (7). If diagnosed early and managed well, disease progression can be slowed, which can prolong the duration of active employment (5). Occupational health professionals can play a significant role in this process.

This study presents the evaluation of work compatibility of a patient with COPD, with the aim being to highlight the importance of cooperation between in-house physicians and occupational disease clinics when evaluating the compatibility of cases with chronic diseases.

\section{CASE}

A 39-year-old male patient was referred to our occupational disease clinic by the in-house physician of his employer with a complaint of dyspnea during work, and for an evaluation of compatibility for occupation.

According to his work history, the patient had worked in recycling for approximately 5 years in an aluminum rim factory, where he was employed to transfer scrap rims to melting pots in a foundry. Approximately one month prior to his visit to our clinic, he had requested to change his position, and was transferred to the production department. His new line of work required him to take 300-500 pieces of rim, each weighing 20-25 kilograms, from a 1 meter-high pallet and to place them on a 1 -meter-high band, and was engaged in the task for approximately 6.5 hours a day (Figure 1). The location in which he worked was right next to the melting furnaces. According to a workplace measurement report, the respirable dust concentrations in the recycling and production departments was $0.086 \mathrm{mg} / \mathrm{m} 3$, which was within the limit values approved in Turkey $(<5 \mathrm{mg} / \mathrm{m} 3)$ (8). The patient had worked as a mechanical assembly worker in a sewing machine production factory for approximately 10 years. His medical history revealed that he had been diagnosed with COPD 2 years earlier. His family history was unremarkable. His past medical history included a smoking habit of 10 packs/year, but he had quit smoking 4 months earlier. During the physical examination, pulmonary auscultation revealed bilateral severely decreased respiratory sounds, while the other system examinations were unremarkable. Hyperlucency was observed in the right lower and middle zone on a postero-anterior (PA) chest X-ray. Bilateral parenchymal emphysematous changes, and a bulla measuring $14 \mathrm{~cm}$ in diameter causing compression on the right middle lobe, were observed in thoracic computed tomography imaging (Figure 2).

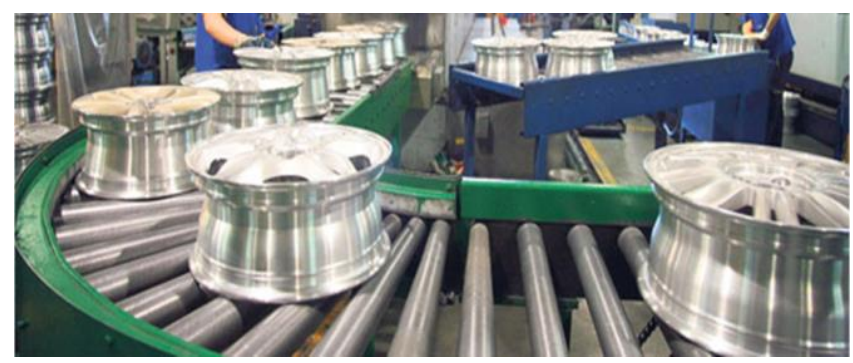

Figure 1: Rim factory (production band) where the patient is employed

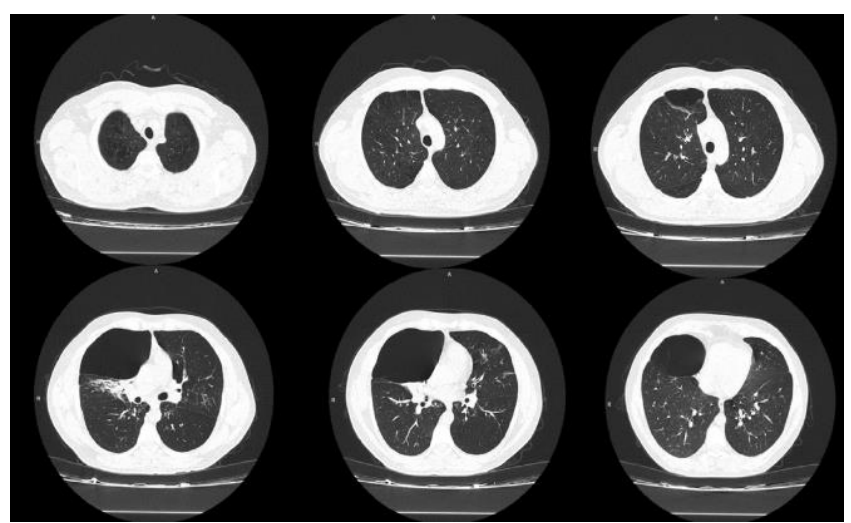

Figure 2: Bilateral parenchymal emphysematous changes, and a bulla measuring $14 \mathrm{~cm}$ in diameter causing compression in the right middle lobe, observed on a computed tomography 
Table 1: Calculation of the energy requirement of the subject's job

\begin{tabular}{|c|c|c|c|}
\hline & $\begin{array}{c}\mathrm{VO}_{2 \mathrm{iob}} \\
(\mathrm{ml} / \mathrm{kg} / \mathrm{min})^{*(11)}\end{array}$ & Time of Job (min) & $\mathrm{VO}_{2 \text { iob }} \times$ Time $(\mathrm{ml} / \mathrm{kg})$ \\
\hline $\begin{array}{l}\text { Standing, Intermittent weight lifting (mean: } \\
22.5 \mathrm{~kg} \text { ) }\end{array}$ & 12.25 & 390 & 4777.5 \\
\hline Standing, Talking & 10.5 & 45 & 472.5 \\
\hline Eating during sitting & 5.25 & 15 & 78.75 \\
\hline Talking during sitting & 5.25 & 15 & 78.75 \\
\hline Combination of Standing/walking & 10.5 & 15 & 157.5 \\
\hline Total & & 480 & 5565 \\
\hline
\end{tabular}

Mean aerobik demand for job activies: $11,6 \mathrm{ml} / \mathrm{kg} / \mathrm{min}$ (5565/480)

* VO2job, aerobic demand of the job

Note: The working time of the case was calculated as 8 hours / day. (it includes one meal break of 1 hour / day and also two need breaks of 15 minutes)

\begin{tabular}{|l|l|}
\hline \multicolumn{2}{|l|}{ Symptom assesment using modified Medical Research Council dyspnea scale (mMRC) } \\
\hline Grade 0 & I only get breathless with strenuous exercise \\
\hline Grade 1 & I get short of breath when hurrying on the level or walking up a slight hill \\
\hline Grade 2 & $\begin{array}{l}\text { I walk slower than people of the same age on the level because of breathlessness or have to stop for } \\
\text { breath when walking at my own pace on the level }\end{array}$ \\
\hline Grade 3 & I stop for breath after walking about 100 yards or after a few minutes on the level \\
\hline Grade 4 & I am too breathless to leave the house or I am breathless when dressing \\
\hline
\end{tabular}

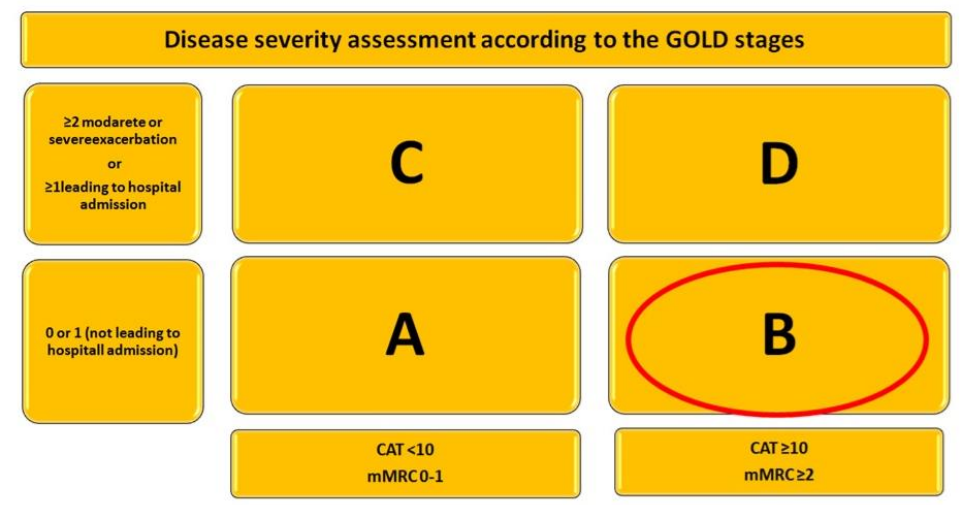

Figure 3: Determination of COPD severity based on symptoms and exacerbation risk. The symptom level of the present case was $m M R C$ stage 2 , and he was evaluated to be in the GOLD B group given the absence of exacerbation

A severe obstructive functional impairment was identified during a post-bronchodilator spirometric evaluation, performed in the stable period (FEV1 $42 \%$ expected (FVC) $84 \%$ expected, FEVI/FVC: $40 \%$ and Body plethysmograph: total lung capacity (TLC): $115 \%$, residual volume (RV): 207\%). The case, who had experienced no exacerbations over the past one year and who was evaluated with an mMRC (Modified Medical Research Council) group 2 dyspnea score, was found to be compatible with GOLD B according to the GOLD (Global Strategy for the
Diagnosis, Management and Prevention of Chronic Obstructive Pulmonary Disease) staging system (Figure 3) (4). The case was investigated for alpha-1-antitrypsin deficiency, having been diagnosed with COPD at the age of $<40$ years. Alpha- 1 genotyping was reported to be normal (PiMM allele).

A cardiopulmonary exercise test (CPET) was performed using a bicycle ergometer and the ramp protocol in order to identify aerobic capacity and to evaluate compatibility for the job. The maximum oxygen consumption (VO2max) 
was calculated as $19.5 \mathrm{ml} / \mathrm{min} / \mathrm{kg}$; with the mean oxygen consumption acceptable for 8 hours of work accepted as $34 \%$ of the VO2max value $(9,10)$. This value in the present case was calculated at $7.8 \mathrm{ml} / \mathrm{min} / \mathrm{kg}$ (34\% of 19.5 $\mathrm{ml} / \mathrm{min} / \mathrm{kg}$ ). The patient's job was analyzed in collaboration with the in-house physician. The required mean oxygen consumption was calculated as $11.6 \mathrm{ml} / \mathrm{min} / \mathrm{kg}$, based on the 2011 Compendium physical activities reference list (11) (Table 1).

The clinical and functional condition of the patient was evaluated alongside the work analysis. The required energy level for the performance of the determined job was suggested to be above the accepted limit value of the case. In addition, the dust, metal smoke and thermal risks in the environment were considered to carry risks for the exacerbation of COPD and disease progression. Furthermore, the properties of the determined task and the working environment were suggested to increase the risk of progression of the bulla found in the lung and for the development of complications. The in-house physician was informed of the importance of regulating the defined job in order to prevent the defined risks. The case was referred to a pulmonary diseases clinic for optimal medical treatment, pulmonary rehabilitation and evaluation for bullectomy, and a reevaluation of the functional condition of the patient was planned after optimal treatment.

\section{DISCUSSION}

The basic steps in a job compatibility evaluation include confirmation of the COPD diagnosis, clinical staging, advanced functional evaluation performed during the stable phase of the disease and a detailed job analysis. The diagnosis was confirmed according to GOLD criteria in this case, and the disease burden on the case was determined. The case was moved away from anything that may exacerbate his COPD, including occupational exposure, and supportive treatment was initiated in which the aim was to increase quality of life case through appropriate pharmacotherapy, and he was evaluated for job compatibility after the optimal conditions were met.

The pathophysiological processes that cause COPD affect exercise capacity. Traditionally, although COPD is defined and graded based on the degree of limitation of FEVI, static and dynamic air trapped (hyperinflation) in the lung has demonstrated to be more important in defining functional dyspnea (12). CPET is a dynamic method, in addition to such static measurements as TLC and RV, and is based on exercise performed under controlled metabolic conditions, and evaluations of the responses of the respiratory system, cardiovascular system and cellular level reveal the holistic response to exercise. The approach allows an objective, quantitative evaluation of the demonstrated aerobic capacity (13). In literature, limit values have been defined based on the concept of aerobic threshold in the studies evaluating job compatibility (14). The aerobic metabolism allows for the long-term maintenance of effort at the complete submaximal level, at which an adequate amount of oxygen is carried to the muscle cells, and most of the ATP required during exercise is provided. The aerobic threshold is defined as the point at which the anaerobic metabolism starts to be used and the blood lactate level starts to increase. The difference from the anaerobic threshold (lactate threshold) is that the blood lactate level is yet $<2 \mathrm{mMol}$. The anaerobic threshold, on the other hand, is the point at which no ventilatory response can be created in response to the developing metabolic acidosis. The blood lactate level is defined generally as $>4 \mathrm{mmol}$, and exercise above this point cannot be tolerated for long. The anaerobic threshold is reached at approximately $50-60 \%$ of $\mathrm{VO} 2 \mathrm{max}$ in sedentary people (15).

For all these reasons, acceptable workload is suggested to be $30-50 \%$ of $\mathrm{VO} 2 \mathrm{max}$ in some studies in literature $(16,17)$. Wu et al. (9) suggested that the defined limit values for workload may vary according to the working hours, and thus suggested $28.5 \%, 31 \%, 34 \%$ and $43.6 \%$ of $\mathrm{VO} 2 \mathrm{max} \%$ values for $12,10,8$ and 4 hours of work, respectively. In the present study, we calculated the oxygen requirement of the case for 8 hours of work, and found it to be below the oxygen requirement for the task to which the case was assigned, indicating his incompatibility with the task.

The most important risk factor in the etiology of COPD has been defined as exposure to tobacco smoke, although occupational exposures to such materials as coal, silica, cement, cadmium, asphalt, coke and welding fumes are also suggested to increase the possibility of development of COPD $(18,19)$. The patient in the present study was employed in the production of aluminum alloy rims, where the substances used in production included aluminum (90\%) and silicon (9\%), and titanium, magnesium and other metals in smaller quantities $(<1 \%)(20)$. Working in the vicinity of melting metal involves a risk of exposure to metal smoke. The case stated that he had been exposed to metal smoke for 3 years and welding smoke for 10 years (30 min/day) prior to his COPD diagnosis, although it is difficult to establish a cause/effect relationship in the development of occupational COPD 
due to the mixed effects of cigarette smoking. It should be further kept in mind that the defined respiratory exposure might lead to the progression of COPD and an increased risk of exacerbation if exposure is not prevented.

Today, the established treatment strategies for COPD are based on the reduction of symptoms and the slowing of rapid progression. These strategies can be summarized as early diagnosis, the prevention of such risk factors as cigarette smoke, etc., the prevention of exacerbations, the control of comorbidities and the preservation of current functional capacity (4). An indispensable proportion of the management of these patients is provided by in-house physicians, since one-third of the lives of individuals are spent at the working environment in a work order of 8 hours. In-house physicians should be aware of the burden of the disease in COPD, as with all other chronic diseases, and they should develop skills in primary and secondary preservation strategies. Early diagnosis and the appropriate management of the disease will allow such patients to remain productive and to stay in active employment for longer (5).

\section{CONCLUSION}

It is important to determine whether an individual is compatible with a defined job to prevent functional capacity being exceeded in cases with limited functionality, and to continue the productivity of the employee. A multidisciplinary approach involving primarily experts in working and occupational diseases is needed in this process.

\section{CONFLICTS OF INTEREST}

None declared.

\section{AUTHOR CONTRIBUTIONS}

Concept - M.A., A.C.B., A.H.Ç.; Planning and Design M.A., A.C.B., A.H.Ç.; Supervision - M.A., A.C.B., A.H.Ç.; Funding - A.H.Ç.; Materials - A.H.Ç.; Data Collection and/or Processing - M.A.; Analysis and/or Interpretation M.A.; Literature Review - M.A.; Writing - M.A., A.C.B.; Critical Review - A.H.Ç., A.C.B.

\section{YAZAR KATKILARI}

Fikir - M.A., A.C.B., A.H.Ç.; Tasarım ve Dizayn - M.A., A.C.B., A.H.Ç.; Denetleme - M.A., A.C.B., A.H.Ç.; Kaynaklar - A.H.Ç.; Malzemeler - A.H.Ç.; Veri Toplama ve/veya İşleme - M.A.; Analiz ve/veya Yorum - M.A.; Literatür Taraması - M.A.; Yazıyı Yazan - M.A., A.C.B.; Eleştirel İnceleme - A.H.Ç., A.C.B.

\section{REFERENCES}

1. Harbers MM, Achterberg PW. Europeans of retirement age: chronic diseases and economic activity. Bilthoven: RIVM 2012.

2. Serra C, Rodriguez MC, Delclos GL, Plana M, Gómez López LI, Benavides FG. Criteria and methods used for the assessment of fitness for work: a systematic review. Occup Environ Med 2007; 64:304-12. [CrossRef]

3. World health organization. Access date: 19.05.2020. Place of access: https://www.who.int/news-room/factsheets/detail/the-top-10-causes-of-death.

4. Global Strategy for the Diagnosis, Management and Prevention of COPD, Global Initiative for Chronic Obstructive Lung Disease (GOLD) 2020. Available at: https://goldcopd.org/gold-reports/.

5. Fletcher MJ, Upton J, Taylor-Fishwick J, Buist SA, Jenkins C, Hutton J, et al. COPD uncovered: an international survey on the impact of chronic obstructive pulmonary disease [COPD] on a working age population. BMC Public Health $2011 ; 11: 612$. [CrossRef]

6. Buist AS, McBurnie MA, Vollmer WM, Gillespie S, Burney $P$, Mannino $D M$, et al: International variation in the prevalence of COPD (the BOLD Study): a population-based prevalence study. Lancet 2007; 370 (9589): 741-50. [CrossRef]

7. Kremer AM, Pal TM, van Keimpema ARJ. Employment and disability for work in patients with COPD: a crosssectional study among Dutch patients. Int Arch Occup Environ Health 2006; 80:78-86. [CrossRef]

8. Tozla mücadele yönetmeliği. Access date: 27.05.2020 Place of access: https://www.resmigazete.gov.tr/eskiler/2013/11/20131 105-9.htm7.

9. Wu HC, Wang MJJ. Relationship between maximum acceptable work time and physical workload. Ergonomics 2002; 45:280-9. [CrossRef]

10. Kim Y, Jung K, Ryu JY, Kim DH, Lee S. A case of fitness to work in a worker with COPD using the exercise stress test. Ann Occup Environ Med 2015; 27:26. [CrossRef]

11. Ainsworth BE, Haskell WL, Herrmann SD, Meckes N, Bassett DR, Tudor-Locke C, et al. 2011 compendium of physical activities: a second update of codes and MET values. Med Sci Sports Exerc 2011; 43:1575-81. [CrossRef]

12. Barnes PJ, Celli BR. Systemic manifestations and comorbidities of COPD. EurRespir J 2009; 33:1165-85. [CrossRef]

13. Ceylan E. Cardiopulmonary exercise testing. J Clin Experimental Invest 2014; 5:504-9. [CrossRef] 
14. Wu HC, Wang MJ. Determining the maximum acceptable work duration for high-intensity work. Eur J Appl Physiol 2001, 85:339-44. [CrossRef]

15. Ghosh AK. Anaerobic threshold: its concept and role in endurance sport. Malays J Med Sci 2004; 11:24-36.

16. Jorgensen K. Permissible loads based on energy expenditure measurements. Ergonomics 1985; 28:365-9. [CrossRef]

17. Ilmarinen J, Tuomi K. Work ability of aging workers. Scand J Work Environ Health 1992; 18 (Suppl 2): 8-10.

18. Omland $O$, Würtz ET, Aasen TB, Blanc $P$, Brisman JB, Miller MR, et al. Occupational chronic obstructive pul- monary disease: a systematic literature review. Scand J Work Environ Health 2014; 40:19-35. [CrossRef]

19. Hu Y, Chen B, Yin Z, Jia L, Zhou Y, Jin T. Increased risk of chronic obstructive pulmonary diseases in coke oven workers: interaction between occupational exposure and smoking. Thorax 2006; 61:290-5. [CrossRef]

20. Kaba M, Donmez A, Cukur A, Kurban AF, Cubuklusu HE, Birol Y. AlSi5Mg0.3 Alloy for the manufacture of automotive wheels. Inter Metalcast 2018; 12:614-24. [CrossRef] 